\title{
Rapid Industrialisation in ASEAN: Some Analytical and Policy Lessons
}

\author{
Hal Hill
}

$A$ LTHOUGH somewhat overshadowed by Japan, the Northeast Asian newly industrialising economies (NIEs), and more recently China, over the past quarter-century the four high-growth ASEAN economies of Indonesia, Malaysia, Singapore and Thailand have grown more quickly than almost any other group of countries. In the early 1960s, with the exception of Singapore, industrialisation had barely begun. What little manufacturing activity there was consisted primarily of simple resource processing industries and the production of a limited array of basic consumer goods for the domestic market. Manufactured exports were minuscule, there were few large modern industrial plants, and the foreign investment presence in manufacturing was very limited beyond what had been established and remained from the colonial era.

By the mid-1990s, all four economies had emerged as significant industrial powers. Annual industrial growth rates of 8-10 per cent or more had been sustained for nearly three decades, far-reaching structural changes had occurred, and, perhaps most important of all, all four had achieved internationally-oriented industrialisation. Industrial growth has been rapid, exceeding developing country averages by $50-100$ per cent in the 1970 s and by a much larger margin since 1980 . The share of the manufacturing sector in output has more than doubled in both Indonesia and Malaysia, and nearly so in Thailand. All four economies have now crossed a key turning point in the long sweep of economic development in that manufacturing output (measured in domestic prices) exceeds that of agriculture. (The absence of such structural change in the slower-growing Philippine economy is striking by contrast.) Manufacturing employment has also grown, at a slower pace owing to rising capital intensity. There has been a spectacular increase in export orientation. In 1970, in all but Singapore, manufactures constituted less than 10 per cent of merchandise exports; in Indonesia they were virtually non-existent. By the mid-1990s, manufactures had become the major engine of export growth, even in

\footnotetext{
1 This article draws on some material used in a textbook in preparation on the ASEAN economies to be published by Oxford University Press, on my work on Indonesian industrialisation (Hill, 1997), and an earlier volume on the topic (Ariff \& Hill, 1985).
}

Hal Hill is Head of the Indonesia Project in the Research School of Pacific and Asian Studies at The Australian National University. 
the resource-rich economies of Indonesia and Malaysia (and even also in the Philippines), contributing at least half and more commonly two-thirds of the total.

The four countries are highly diverse, and have little in common other than geographic proximity, high growth, and a commitment (in varying degrees) to openness. The ratio of GDP per capita from the highest to the lowest is 25:1 (or, in PPP terms, 8:1). Their populations range from more than $200 \mathrm{~m}$ to fewer than $3 \mathrm{~m}$. Exports as a share of GDP vary from about 180 per cent to 250 per cent. There are also great differences in their history, institutions, policy-making structures, foreign investment environments and natural resource endowments. Owing to this combination of great diversity but rapid growth, the ASEAN industrialisation experience is of enormous significance for its policy and analytical lessons. These four countries constitute an ideal laboratory for the examination of a number of important issues related to the determinants and sustainability of rapid industrialisation in developing countries. This article explores some of these lessons. ${ }^{2}$

Since industrial growth and economic growth almost invariably go hand-inhand, the explanations for rapid industrial growth are to be found in those factors which underpin high rates of economic growth: sound macroeconomic management, international orientation, observance of property rights and judicial independence, and investments in human capital and physical infrastructure. This article is not concerned with these general factors, but rather takes them as given and focuses instead on the specifics of a range of industrial policy issues.

\section{Industrial Policy}

The role of industry policy, defined here as a deliberately non-neutral incentives regime, in ASEAN's rapid industrialisation is an extensively debated development policy issue, much of it focused on Northeast Asia, but now also engaging ASEAN. ${ }^{3}$ Two contending paradigms have emerged. According to one, the major contribution of governments has been in getting the 'fundamentals' right: macroeconomic stability, predictable and stable policy regimes, improved physical infrastructure and education, a reasonably adequate system of property rights and legal infrastructure, and increasing openness to international commerce. The other paradigm accepts some or all of the above prescriptions, but argues that it is an insufficient recipe for industrial success. This school rejects an emphasis based primarily on economic liberalism and static comparative advantage. It argues that Ko-

\footnotetext{
${ }^{2}$ No empirical material is included (a set of comparative tables covering these topics is available on request from the author). ASFAN country studies include Ariff (1991), Jomo (1993), and Athukorala and Menon (1997) on Malaysia, Medhi Krongkaew (1995) on Thailand, and Lim and Associates (1988, ch. 9) on Singapore, and Medalla and Associates (1995) on the Philippines.

${ }^{3}$ An example of the orthodox approach to this subject, modified by the constraints imposed by its authorship, is World Bank (1993). Smith (1995) provides a comprehensive survey of the Fast Asian literature, from a largely neoclassical perspective. Influential East Asian case studies among the interventionist school include Amsden (1989) on Korea, Johnson (1982) on Japan, and Wade (1990) on Taiwan. Hughes (1988) is a useful airing of competing views in the debate.
} 
rea, Taiwan and Japan owe their success to selective industrial policies: targeting industries, 'picking winners', and deliberately 'getting prices wrong' through fiscal incentives, subsidised credit, import protection, and direct investment.

Indonesia, Malaysia and Thailand ${ }^{4}$ have industrialised rapidly, and their governments, particularly in Indonesia, have intervened extensively at the industry level. Yet the research emerging on this topic finds little evidence to support the claim that selective industrial policies have contributed to their success. The standard tools of industrial policy have been employed in all three economies, although over time deliberate policy-induced distortions have declined. Inter-industry variations in protection have been considerable, especially in Indonesia. A large state enterprise sector is present, especially in Indonesia and to a lesser extent Malaysia. Subsidised credit and interest rate controls have existed in all three countries for at least some of the past 25 years. Fiscal incentives have also been employed. Moreover, official policy pronouncements give the impression of coherence, in the sense that governments have stated their intention to develop specific industries (for example, automobiles) or sectors such as heavy and technology-intensive industry.

The issue here is whether policy implementation has matched the official statements, and whether it is possible to discern any development impacts from these interventions. Establishing cause and effect in this area is difficult: the causal mechanisms are still not well understood, there are likely to be long lags in the relationships, and detailed micro-level information is required to address the question definitively. On the first general question, it is clear that industrial policy has lacked coherence. Ministries of finance and central banks have been concerned primarily with macroeconomic stability and have propounded market-oriented microeconomic strategies. They have usually been able to keep advocates of selective industrial policy in check, especially during periods of economic difficulty. In any case, the interventionist groups have rarely spoken with one voice. Typically, they have comprised a diverse group of interests, ranging from those with a genuine industrial promotion mission to brazen rent-seekers.

The record of industrial policy in these three countries is therefore quite unlike that of Northeast Asia. Promotional measures in ASEAN have been prone to abuse, implementation has been sporadic and often short-lived, and there has been little systematic attempt to link incentives to tightly defined performance criteria. Not surprisingly, studies of the relationship between inter-industry variations in government assistance (for example, through protection and credit subsidies) and subsequent (lagged) performance, according to a variety of measures, have found little evidence of causality. In the case of Indonesia, a survey of selective policy instruments introduced or extended in the $1970 \mathrm{~s}$ and early $1980 \mathrm{~s}$ - protection, credit subsidies, state enterprises - detected very little evidence of such a strategy having 'worked' according to a range of subsequent performance criteria (see Hill, 1996). Similarly, Warr's (1994) study of several policy correlates of export performance in

\footnotetext{
${ }^{4}$ Singapore is a special case because of its almost completely open boundaries, although extensive intervention exists in the form of state ownership and selective fiscal incentives.
} 
Thailand during 1970-89 revealed a remarkably consistent picture of negative coefficients for all variables and time periods. In the case of Malaysia, it is very difficult to find any evidence that the government's promotion of heavy industry during 1978-86 stimulated efficient industrial growth (Athukorala \& Menon, 1997).

Thus theory, empirical evidence, and the political economy of industrial policymaking all provide little support for the notion that a selective incentives strategy has contributed to the region's rapid, internationally oriented industrialisation. Rather, the limited attempts to quantify the inter-industry effects of micro-level interventions in ASEAN support the 'fundamentals' camp, in the sense that these countries have industrialised extremely rapidly without a coherent industry policy. Moreover, growth appears to have been more efficient and rapid during periods of policy liberalisation. The link between the two is extremely difficult to verify empirically, as even the huge World Bank project on the subject demonstrated. ${ }^{5}$ But, as argued below, there appears to be a strong and positive association between the rate of growth of total factor productivity (TFP) and a more liberal trade regime.

\section{The Role of Foreign Investment and Technology}

The role of foreign direct investment (FDI) in the ASEAN economies, and perceptions about that role in the host economy, have changed substantially over the past quarter century. In the mid-1970s, for example, only Singapore had an unambiguously open stance (although Malaysia, too, was generally quite open). In the 1990s, host economies are more likely to worry that they are attracting insufficient foreign capital, and the principal policy issue now is whether host economies should adopt a neutral or pro-active strategy towards FDI. Major business conglomerates in the region are now more confident of their capacity to negotiate with multinational corporations (MNCs), and for the first time all countries have emerged as outward investors, Singapore on a large scale.

Singapore's FDI policies are often held up as a model for how developing countries might manage the MNC presence (for a useful summary, see Low et al., 1993). Their main features include: few sectoral restrictions on FDI entry, few ownership and personnel restrictions, policy consistency, an active role in attracting foreign firms to Singapore and ensuring that they can begin operations with minimal disruption, the liberal and aggressive use of fiscal incentives (often on a firm-specific basis), explicit attempts to extract the benefits of FDI through the establishment of joint venture technology and training programs, and a 'hard' regime allowing no scope for tax evasion, corruption, and import protection.

The approach in the other three countries has gradually come to resemble Singapore's. Initially, their investment boards were ambivalent in the management of their twin roles of promotion and regulation, with the result that neither was effec-

\footnotetext{
${ }^{5}$ See Papageorgiou et al. (1991) and the review of this seven-volume project by Greenaway (1993).
} 
tively achieved. ${ }^{6}$ By the 1990 s, the crucial difference is that the more open trade regimes have removed most of the 'tariff bargaining' which was a frequent feature of import-substituting MNC entry in the 1970s. The shift towards export orientation has therefore not only attracted internationally efficient foreign capital, but also altered the political economy of investment regulation. Fiscal incentives remain present in some countries, but they have been de-emphasised. Indonesia abolished them completely in 1984, in the context of sweeping taxation reforms. By the late 1980 s, it was attracting record FDI inflows without having to offer costly and corruption-prone incentives. Singapore has retained such incentives, but in the context of a completely open economy and a ruthlessly incorruptible bureaucracy. In any case, it is not obvious that such an incentives regime is essential, as compared to the alternative of Hong Kong-style uniformly low rates without concessions. Hong Kong's superior record in the growth accounting exercises referred to below constitutes prima facie support for this proposition.

As noted, technology policy and strategies relate more closely to the issue of government intervention to overcome market failure. In particular, it is argued that markets will under-invest in most forms of education, training and R\&D. Since these are crucial ingredients to rapid economic development, so the argument goes, governments have a role to play, both at a general level and in quite industry-specific domains. Such a school of thought adopts an intermediate position between the orthodox neo-classical prescription and the more interventionist approach. ${ }^{7}$ It shares with the former a concern about the consequences of extensive import protection, credit subsidies, and an inefficient state enterprise sector. But it has more in common with the latter group in its willingness to advocate a larger government role in providing education, in playing a catalytic role in technological development, and, in certain tightly defined instances, in fostering infant industry growth.

The issue is of particular relevance to the three lower-income ASEAN countries: all have experienced a first-round of labour-intensive, export-oriented industrialisation which, building on low labour costs, was propelled by a combination of competitive exchange rates, reforms which placed at least export-oriented industries on a near free-trade footing, and a reasonably adequate international transport and communications infrastructure. However, rising wages, especially in Malaysia and Thailand, are shifting these countries' comparative advantage out of labour-intensive industries, notwithstanding large-scale labour immigration. These countries must now compete downwards with lower-wage countries such as China, and upwards with the much stronger technological base of the NIEs. While the ASEAN record in the provision of primary education is good, it is much weaker in the areas of secondary, tertiary and vocational education, in industry-level R\&D institutes, and in firm-level R\&D activity. There is strong evidence that Thailand's current economic problems, though primarily macroeconomic in origin (particularly in its exchange

\footnotetext{
${ }^{6}$ In the words of Helen Hughes (1993:15): 'Until the 1980s, the role of the ASEAN member country Investment Boards, other than of the Economic Development Board of Singapore, was to ration access to domestic monopolistic markets created by protection, fiscal, credit and other incentives.'

${ }^{7}$ Lall $(1992,1996)$ exemplifies the approach of this school.
} 
rate management), were exacerbated by the difficulties of upgrading in the face of acute human capital shortages.

Technology is being imported on a large scale, through FDI and skilled labour inflows. However, commensurate local absorptive capacities are not yet developing quickly. Private sector R\&D and training are very limited, in part because firms are unable to appropriate the returns from such investment in an environment where labour mobility is very high. Government research institutes, with a few exceptions, are poorly funded and weakly linked to the private sector. There is thus a case for governments stimulating private sector $\mathrm{R} \& \mathrm{D}$ by funding dynamic, private sectordriven research institutes, by fostering the development of effective cooperative institutions at the industry level which overcome the appropriability problems of freeriders, and by carefully structured fiscal incentives. Thus far, only Singapore has made substantial progress in these areas. Within the space of a decade, its R\&D expenditure as a percentage of GDP has risen from something like the middleincome norm (about 0.3 per cent) in the mid-1980s to close to the OECD average (1.5 per cent). The other three countries, while effective macro-managers, have a much poorer record of innovative micro-level management.

Thus the evidence on 'state and market' in ASEAN's industrial success is mixed. There is little persuasive evidence which demonstrates that governments have achieved rapid, efficient growth through selective industrial policies which have sought to systematically direct the allocation of resources towards industries that have later become internationally competitive. Rather, many of the benefits of this selective intervention, whether in the form of protection, state enterprises or subsidised credit, have been captured by vested interests. At the same time, with the exception of Singapore, governments have tended to underinvest in areas where markets do not operate effectively, like certain types of support infrastructure needed to promote an efficient industrial sector. This record is all the more puzzling given that Indonesia, Malaysia and Thailand have all developed effective agricultural extension services in which governments played an important role in facilitating the rapid introduction and dissemination of new agricultural technologies.

\section{Sources of Growth}

The debate over the various growth accounting estimates goes to the heart of the origins and the sustainability of Southeast Asian economic growth. This topic became internationally prominent with Paul Krugman's (1994) provocative 'inspiration versus perspiration' formulation. Krugman employed TFP analysis to argue that there was nothing 'miraculous' about rapid East Asian development, using Singapore as an example. The record, he maintained, could be explained essentially by a primitive, Stalinist model of factor accumulation, in which growth was accounted for principally by the expansion of inputs, with very little unexplained residual in the equations, suggesting low or even negative TFP growth. If Krugman is correct, the implications are far-reaching: the Southeast Asian success would then have to be seen primarily in terms of a capacity to achieve high rates of saving and 
labour force growth which, once falling to 'average' levels, would see the spectacular growth rates likewise subsiding.

Since the pioneering work of Jorgenson and others, economists have decomposed growth into its major elements: labour, capital, and a residual (perhaps misleadingly named) TFP. Recent studies have generated more sophisticated estimates, which allow not only for the quantitative expansion of factor inputs but also qualitative improvements, notably to allow for human capital expansion. Capital stock estimates have been improved along with more reliable data series, although quality improvements have been more difficult to incorporate, other than simply as market-price estimates. ${ }^{8}$ Improved estimates of factor inputs have in turn reduced the magnitude of TFP growth, since the unexplained residual is thereby smaller.

A large number of TFP estimates for Southeast Asia have been undertaken in the past decade, as the data base has improved and as interest in the topic has grown. ${ }^{9}$ Certain features of these data deserve emphasis. First, in international perspective, the four high-growth Southeast Asian countries, Singapore excepted, have generally achieved higher TFP growth than the average for developing countries (see for example Bosworth, Collins and Chen, 1995, and Nehru and Dhareshwar, 1994). So much of the literature has focused on the Young (1994) and Krugman Singapore-Hong Kong comparison that the broader East Asian achievement is frequently overlooked. Second, the range of these estimates is very large. Even for the same country and time period, the differences are frustratingly significant in a number of cases. This alone warns against using these data in anything other than a highly cautious manner. ${ }^{10}$ Probably the most useful comparisons can be made for numbers generated by the same project, on the assumption that with a common methodological framework one can at least be confident that differences cannot be attributed to variations in assumptions and data bases.

Nevertheless, there are systematic differences in TFP growth over time in each country. In Indonesia, TFP growth in the 1970s was positive but modest, presumably reflecting the influence of a sudden return to high growth of investment and GDP in response to the oil boom. During the recession of the 1980s, it fell (though not apparently in non-oil manufacturing) before rising again during the period of export-oriented development. A similar trend is evident in Malaysia, except that the acceleration since the mid-1980s has been even more pronounced. The Philippine record mirrors its overall economic performance: during the 1970s TFP grew at a rate comparable to its neighbours, although its manufacturing perform-

\footnotetext{
${ }^{8}$ The issue of quality improvements highlights a major analytical conundrum: if all factor inputs are measured comprehensively, both quantitatively and qualitatively, there should not be any unexplained residual. Morcover, it is difficult empirically to estimate TFP independent of factor accumulation, since technical change generally takes place in the form of embodied factor augmentation.

${ }^{9} \mathrm{~A}$ tabular summary of these estimates is available on request from the author. See also Chen (1997).

${ }^{10}$ A particular concern, argued forcefully by Harberger (1997), is the highly aggregated nature of most of the estimates, many of which are computed simply for the whole economy without any sectoral disaggregation. Even where sectoral estimates are presented, the data may be misleading in an economy experiencing rapid structural change owing to problems of aggregation.
} 
ance was poorer. Its record, however, was disastrous in the first half of the 1980s, and has shown little evidence of recovery since. Thailand has not recorded such sharp swings in TFP growth, presumably reflecting the absence of major variations in its policy regime. Here, too, there has been strong growth since the mid-1980s. The conclusion from these country studies is that TFP growth moves broadly in line with GDP. It appears in addition that liberalisation and international orientation have resulted in faster TFP growth, consistent with the notion that such a strategy promotes greater efficiency. This is illustrated by the TFP-GDP growth differentials in Malaysia, Thailand and Indonesia (in the latter, at least for non-oil manufacturing) in the 1970s as compared to the period since the mid-1980s.

Singapore occupies a special position in this analysis. It was central to Krugman's analysis, and it is the only one among the high-growth four for which negative numbers have occurred quite frequently. However, to compare it with some sort of Soviet-style input accumulation model is far-fetched. True, some other economies have achieved comparable GDP growth rates with lower saving and/or labour force growth rates, suggesting the possibility of some sort of 'over-saving', possibly linked to the country's compulsory saving arrangements. But it does not follow that such growth is sustained only through factor accumulation. Singapore's completely open economy ensures that its investments are internationally efficient, whereas in the Soviet model exposure to international markets revealed that much of its traded sector was not internationally competitive.

There are two additional reasons for caution in drawing too much from the Singapore data. First, its high savings have generated lower returns than the other NIEs partly because Singapore has invested much more in public goods which do not generate an immediate, quantifiable return: its housing is generally better, and its public infrastructure (parks, roads, airport, and so on) is of higher quality. According to these quality of life indicators, therefore, Singapore scores more highly. Second, TFP growth appears to have accelerated sharply since the mid-1980s, according to all series, to levels which are at least comparable to those of other East Asian countries. Over this period, its growth rate has been maintained even as its labour force growth has approached zero, and saving rates have levelled off. The reasons for this sudden increase in TFP growth are difficult to discern, and probably at least in part reflect analytical weaknesses in the concept and measurement of TFP. It may be a result of rapid restructuring over this period, including the shift into higher value-added activities.

Thus, in sum, while it is true that Southeast Asian countries have achieved high savings rates, their TFP performance has also generally been impressive. The assertion that growth has primarily been the result of 'perspiration' is therefore misleading. It is also important to emphasise the nexus between TFP growth and liberalisation, which has been clearly evident over the past decade.

\section{The Size Distribution of Industry}

The size distribution of industry raises public policy issues, such as how well markets operate in remote rural areas where many small-medium enterprises (SMEs) 
are located, and whether there is any case for special SME assistance. It also raises industrial organisation issues associated with the explanation of international differences in the size structure of industry and of changes in this structure over time. ${ }^{11}$

First, the industrial organisation issues. SMFs (defined as firms employing up to 200 workers) in ASEAN constitute at least 85 per cent of all industrial establishments; they employ 30-60 per cent of the industrial workforce; they generate between one-fifth and one-third of total output. Surprisingly, there appears to be no systematic correlation between SME shares and per capita GDP. An inverse relationship might have be expected, on the assumption that smaller units become relatively less important as incomes rise, but there is no clear evidence of this. ${ }^{12}$

Much of the SME literature assumes that such firms become less important over the course of industrialisation (Anderson, 1982). The only ASEAN country for which comprehensive time series data are available on the size distribution of manufacturing, spanning more than two decades, is Singapore. During that country's rapid industrialisation, there has been a clear shift to units of large scale. In 1965-92 the share of firms with 300 or more employees doubled on the added value measure and more than doubled on the employment measure. By contrast, shares of the smaller firm-size groups contracted sharply, and by 1992 were well under one-half the 1965 figures for both employment and added value. The sharpest changes in size distribution occurred during 1965-75, after which the value added and employment shares of the largest group (300 or more employees) was virtually constant. One intuitively plausible explanation for these trends is that the early period coincided with Singapore's major push into labour-intensive, exportoriented industries, involving large plants in electronics, textiles, and other activities. The SME sector did not shrink absolutely, but its share fell quickly as most of the new plants were in the 300-plus group. After this transitional phase, the expansion rates of the various size groups did not greatly differ, suggesting that, as the industrial structure upgrades to a more human-capital intensive phase, there continues to be a role for the SME group, particularly among the larger of these firms.

In analysing trends in size distribution, it is important to understand not only the aggregate trends, but also the dynamics of these changes. From the point of view of both efficiency and equity it matters a lot whether, for example, a trend towards agglomeration occurs because SME firms are displaced by, or themselves grow into, larger units. It is rarely possible to answer such a question at the macro level because detailed firm-level records are not available. However, a recent analysis of such data from Indonesia over the period 1977-91 (see Aswicahyono et al., 1996) computes two sets of size distribution. The first, following the conventional approach, classifies firms by their size in the year of enumeration, while the

\footnotetext{
11 The best general survey on this subject for East Asia as a whole is Berry and Mazumdar (1991.

12 Two plausible hypotheses for the absence of such a relationship are natural resource endowments, which can result in large-scale resource-intensive investments at quite low levels of per capita income, and high levels of import protection, which encourage the development of scale-intensive industries. Conversely, this factor cannot be the whole story, as the resource-poor Philippines also has a low value added share for SME, while for resource-rich Malaysia the share is high.
} 
second classifies them by their size in the base year (1975 - the year the data set begins - or, if later, the year the firm started operations). The second set of data reveals a good deal of dynamism on the part of smaller firms, as shown by the fact that the share of the 20-99 employee group is consistently higher in the 'initial year' series. In the current year series, there is no significant change in the distribution, other than a gradual increase in the middle group. In other words, smaller firms appear to be 'graduating', in contrast to popular (and populist) perceptions that they are struggling to survive.

The policy approach to SMEs in ASEAN has changed over the past decade, based on the gradual realisation that, for all the government rhetoric concerning the importance of SMEs, paradoxically public policies have often actually discriminated against them. ${ }^{13}$ Trade policies have been biased against SMEs to the extent that they have offered above-average protection to large-scale intensive industries. Fiscal incentives have had a similar effect when, as is often the case, they apply only to investments of a certain minimum size. Interest rate ceilings have often harmed SMEs, since banks cannot recoup the higher per unit administrative costs of dealing with such firms. Complex regulatory regimes add an additional cost penalty for SMEs, since they are frequently fixed cost in nature. In Indonesia, the country with the most pervasive regulatory regime, there may be a 5-8 per cent cost penalty for SMEs, according to as yet unpublished research. The evidence from ASEAN, and elsewhere, is that SME programs which are not in some respects 'market friendly' have not been successful in promoting efficient industrial development. Examples include enforced subcontracting schemes, reservation schemes, and general requirements or exhortations that large firms assist smaller units in some way. Indonesia has developed the most comprehensive set of programs in this area, generally with little success. Conversely, its government has also introduced successful and innovatory programs in finance, which have both reduced costly subsidies and enabled small borrowers to obtain better access to formal credit markets (see Patten \& Rosengard, 1991). Another illustration of the scope for simple reform facilitating the development of a more efficient and accessible capital market has been highlighted in the research in Thailand demonstrating the nexus between clear land titles, the efficient functioning of the credit market, and agricultural productivity (see Feder et al., 1988).

\section{Industrial Concentration and Competition Policy}

The two related issues of concentration and competition are becoming increasingly important in the three lower-income countries. They rarely rate a mention in the completely open Singapore economy: except perhaps for a very few internationally oligopolistic industries, concentration is not an issue if all sectors are fully tradable and there are no barriers to international trade. As a corollary, obviously, the trade regime constitutes the most effective tool of competition policy.

${ }^{13}$ Bruch and Hiemenz (1984) were among the first to document these 'perverse interventions' in the Southeast Asian context in some detail. See also the country studies in Meyanathan (1994). 
Detailed data are lacking on seller concentration for all four economies, but the general picture is clear. The most complete information is for Indonesia (see Bird, 1997, on which this paragraph relies), whose experience approximates developing country norms (see, for example, Kirkpatrick et al., 1984: chapter 3). Seller concentration is high in Indonesia, with more than half of manufacturing output originating from industries in which the four largest firms' share of the industry's output is at least 40 per cent; concentration ratios in excess of 70 per cent are quite common. While these figures primarily reflect the influence of industrial infancy and scale, there is as yet no clear downward trend. Even during the period of trade liberalisation from 1985 onwards, while there was a slight decline, it was not statistically significant. Similar comments apply to the trade-adjusted concentration ratios.

Continuing high levels of concentration have triggered a debate in several countries concerning the merits of some form of competition policy. Proposals have included price surveillance and control, some form of trade practices commission, and (the unusual approach of the Indonesian Minister for Investment) a prohibition on existing firms in highly concentrated industries from expanding their productive capacity except for export. However, much of the discussion has lacked analytical focus. Moreover, proponents of increased intervention generally overlook the link between competition and trade policy (except that, paradoxically, many of them oppose trade liberalisation, or consider it irrelevant), and ignore the fact that restraints on trade are often caused directly or indirectly by governments.

In Indonesia, for example, some form of competition policy has been advocated since the early 1980s. The agenda which drives this debate has little to do with competition policy as is normally understood by the term. Two key elements underpin it. The first is that the term 'monopoly' is often really discreet code for the highly privileged business activities of members of the extended family of President Soeharto. Several of these people have built up vast business empires in the space of just 10-15 years on the basis of the country's highly personalistic commercial practices, which often by-pass the usual checks and balances. ${ }^{14}$ Direct criticism of these business arrangements is not possible, and so instead public comment focuses more generally on monopolies. But it is clear that advocates of reform in this instance are really concerned about the issues of transparency, non-preferential treatment, and pluralistic political structures, rather than some elaborate bureaucratic construct to promote competition policy. The second element underpinning the agenda derives from bureaucratic power interests within the government. Deregulation may have become the principal economic policy slogan in Indonesia over the past decade, but most of the technical departments have been reluctant to surrender the authority which generates lucrative rents. This results in the paradox that senior policy-makers are advocating the introduction of more, not fewer, regulations

\footnotetext{
${ }^{14}$ These cases are extensively documented in the 'Survey of Recent Developments' in the 1990s issues of the Bulletin of Indonesian Economic Studies.
} 
to promote competition, while at the same time they preside over a regulatory environment which actively discourages trade. ${ }^{15}$

The problem therefore is more likely to be government failure rather than market failure, and the solution is a complete overhaul of the government's administrative structures and procedures, combined with continuous import liberalisation. In such an environment, the establishment of some sort of competition commission is more likely to exacerbate, rather than solve, the problem, as well as presenting lucrative opportunities for the country's fledgling commercial law industry. There may be a case for some form of government surveillance, in genuinely non-tradable sectors, such as wholesale and retail trade, and utilities. But this is a low priority issue compared with the pressing task of bureaucratic reform. The problem is more serious in Indonesia than its neighbours, owing to its traditionally less open economy and its deeply entrenched problems of corruption, but similar issues are being debated in The Philippines and Thailand.

\section{Concluding Comments}

This article has focused on some of the key analytical and policy lessons from the rapid industrialisation in several Southeast Asian countries over the past three decades. These relate to the issue of industrial policy, strategies towards foreign investment and technological development, the sources-of-growth debate, and industrial concentration and the changing size distribution of industry. By way of conclusion, it would be useful to relate briefly the optimistic tone of this paper to the financial difficulties being experienced by these economies.

The first and obvious point to make is that, even in rapidly growing economies, economic development is rarely a smooth, continuous process. Even well-managed economies encounter problems: one only has to recall the serious recession in Indonesia, Malaysia, and Singapore in the mid-1980s to appreciate this point. Second, this article has been concerned primarily with industrialisation issues, whereas the current problems have their origins mainly in the macroeconomic realm: exchange rates have been closely (or completely, in Thailand's case) pegged to the US dollar, which has resulted in significant appreciation against the currency of the region's major investor and trader, Japan. These rigid exchange rate regimes, in the context of large current account deficits and (in Malaysia and Thailand) rising real wages, offered an inviting target to currency speculators.

These developments also need to be seen in the long sweep of economic development. There is no reason to believe that, given swift macro- and microeconomic reforms, these economies cannot return to rapid growth. Nor do the recent difficulties invalidate any of the propositions advanced here. Indeed, to the extent that supply-side deficiencies have contributed to the current difficulties, the

\footnotetext{
${ }^{15} \mathrm{~A}$ senior official in the Ministry of Industry and Trade recently revealed that an exporter is liable to pay about 4,400 levies imposed by various government tiers and departments. This number refers only to officia/levies; the number of illegal levies is unknown but considerable (Jakarta Post, 11 July 1996).
} 
case adumbrated for more investment in education and basic technological capacity, and for a cleaner, more efficient regulatory regime, is an even stronger one.

\section{References}

Amsden, A. (1989), Asia's Next Giant: South Korea and Late Industrialization, Oxford University Press, New York.

Anderson, D. (1982), 'Small Industry in Developing Countries: A Discussion of Issues', World Development 10: 913-48.

Ariff, M. (1991), The Malaysian Economy: Pacific Connections, Oxford University Press, Singapore.

— \& H. Hill (1985), Export-Oriented Industrialization: The ASEAN Experience, Allen \& Unwin, Sydney.

Aswicahyono, H., K. Bird \& H. Hill (1996), 'What Happens to Industrial Structure When Countries Liberalize? Indonesia Since the mid-1980s', Joumal of Development Studies 32: 340-63.

Athukorala, P. \& J. Menon (1997), 'Export-led Industrialisation, Employment and Equity: The Malaysian Case', Agenda 4: 63-76.

Berry, A. \& D. Mazumdar (1991), 'Small-Scale Industry in the Asia-Pacific Region', Asian-Pacific Economic Literature 5(2): 35-67.

Bird, K. (1997), An Analysis of Market Structure and Competition in Indonesian Manufacturing Industry, unpublished PhD dissertation, Australian National University, Canberra (forthcoming).

Bosworth, B., S. Collins \& Y-C. Chen (1995), 'Accounting for Differences in Economic Growth', paper presented to a conference on Structural Adjustment Policies in the 1990s: Fxperience and Prospects, Institute of Developing Economies, Tokyo (5-6 November).

Bruch, M. \& U. Hiemenz (1984), Small- and Medium-Scale Industries in the ASEAN Countries: Agents or Victims of Economic Development?, Westview, Boulder.

Chen, E. (1997), "The Total Factor Productivity Debate: Determinants of Economic Growth in Fast Asia', Asian-Pacific Economic Literature 11(1): 18-38.

Feder, G. et al. (1988), Land Policies and Farm Productivity in Thailand, Johns Hopkins University Press for the World Bank, Baltimore.

Greenaway, D. (1993), 'Liberalising Foreign Trade Through Rose Tinted Glasses', Economic Journal 103: 208-22.

Harberger, A. (1997), 'Reflections on Economic Growth in Asia and the Pacific', Journal of Asian Economics 7: 365-92.

Hill, H. (1996), 'Indonesia's Industrial Policy and Performance: "Orthodoxy' Vindicated"', Economic Development and Cultural Change 5(1): 147.74.

- (1997), Indonesia's Industrial Transformation, Institute of Southeast Asian Studies, Singapore.

Hughes, H. (ed.) (1988), Achieving Industrialization in East Asia, Cambridge University Press, Cambridge. 
(1993), 'An External View', pp. 1-25 in Low et al., Challenge and Response: Thirty Years of the Economic Development Baard, Times Academic Press, Singapore.

Johnson, C. (1982), MITI and the Japanese Economic Miracle, Stanford University Press, Stanford.

Jomo, K. (ed.) (1993), Industrialising Malaysia: Policy, Performance, Prospects, Routledge, London.

Kirkpatrick, C., N. Lee \& F. Nixson (1984), Industrial Structure and Policy in Less Developed Countries, Allen \& Unwin, London.

Krugman, P. (1994), 'The Myth of Asia's Miracle', Foreign Affairs 73(6): 62-78.

Lall, S. (1992), 'Technological Capabilities and Industrialization', World Development 20: 165-86.

(1996), 'Paradigms of Development: The East Asian Debate', Oxford Development Studies 24: $111-32$.

Lim, C. \& Associates (1988), Policy Options for the Singapore Economy, McGraw-Hill, Singapore.

Low, L. et al. (1993), Challenge and Response: Thirty Years of the Economic Development Board, Times Academic Press, Singapore.

Medalla, E. \& Associates (1995), Catching up with Asia's Tigers: Philippine Trade and Industrial Policies, Philippine Institute for Development Studies, Manila.

Medhi Krongkaew (ed.) (1995), Thailand's Industrialization and its Consequences, Macmillan, London.

Meyanathan, S. (ed.) (1994), Industrial Structure and the Development of Small and Medium Enterprise Linkages: Examples from East Asia, EDI Seminar Series, World Bank, Washington DC.

Nehru, V. \& A. Dhareshwar (1994), 'New Estimates of Total Factor Productivity Growth for Developing and Industrial Countries', World Bank, Washington DC (Policy Research Working Paper 1313).

Papageorgiou, D., M. Michaely \& A. Choksi (eds) (1991), Liberalizing Foreign Trade, Basil Blackwell for the World Bank, Cambridge, Mass.

Patten, R. \& J. Rosengard (1991), Progress with Profits: the Development of Rural Banking in Indonesia, International Center for Economic Growth, San Francisco.

Smith, H. (1995), 'Industry Policy in Fast Asia', Asian-Pacific Economic Literature 9(1): 17-39.

Wade, R. (1990), Governing the Market: Economic Theory and the Role of Government in East Asian Industrialization, Princeton University Press, Princeton.

Warr, P. (1994), 'Myths about Dragons: The Case of Thailand', Agenda 1: 215-28.

Young, A. (1994), 'Lessons from the East Asian NICs: A Contrarian View', European Economic Review 38: 964-73.

For helpful comments on an earlier draft, I am indebted to Chandra Athukorala, two anonymous referees, and the editor. 